${ }^{7}$ Kemp RB. Effect of the removal of cell surface sialic acid on aggregation in vitro. Nature 1968;218:1255.

${ }^{8}$ Steinhardt RA, Lundin L, Mazia D. Bioelectric responses of the echinoderm egg to fertilisation. Proc Natl Acad Sci 1971;68:2426-30.

${ }^{9}$ Macieira-Coelho A, Avrameas S. Modulation of cell behaviour in vitro by the substratum in fibroblastic and leukaemic mouse cell lines. Proc Natl Acad Sci 1972;69:2469-73.

${ }^{10}$ Mazia D, Schatten G, Sale W. Adhesions of cells to surfaces coated with polylysine. Applications to electron microscopy. $J$ Cell Biol 1975;66: 198-200.

" Husain OAN, Millet JA, Grainger JM. Use of polylysine coated slides in preparation of cell samples for diagnostic cytology with special reference to urine sample. J Clin Pathol 1980;33:307-11.

${ }^{12}$ Duguid HLD, Wood RAB, Irving AD, Preece PE, Cuschieri A.
Needle aspiration of the breast with immediate reporting of material. Br Med J 1979; ii: 185-7.

${ }^{13}$ Husain OAN, Page Roberts B, Millet JA. A sample preparation for automated cervical cancer screening. Acta Cytologica 1978;22: 15-21.

${ }^{14}$ Husain OAN, Watts KC. The rapid demonstration of nucleic acids using 'oxidised' gallocyanin and chromic potassium sulphate: methods and applications. J Clin Pathol 1984;37:99101.

is Tucker JH, Shippey G. Basic performance tests on the CERVIFIP Linear Array Prescreener. Analytical and Quantitative Cytology 1983;5:129-37.

Requests for reprints to: Dr OAN Husain, Consultant Pathologist, The Division of Pathology, St Stephen's Hospital, Chelsea, London SW10 9TH, England.

\section{Semiautomated method for quantitative urine culture}

\author{
SG EDMONDSON, LJ ENRIGHT \\ Department of Microbiology, Cheltenham General \\ Hospital, Cheltenham
}

Examination of urine must be the most frequently performed task in any bacteriology laboratory with a large service commitment. Generally, an attempt is made to determine the numbers of viable bacteria present in the specimen, and a variety of methods have been used to this end. At the time of publication of his papers in the $1950 \mathrm{~s},{ }^{1-3}$ from which the criteria for interpretation of bacterial counts in urine samples were defined, Kass used the agar pour plate method. Hoeprich, in 1960, ${ }^{4}$ introduced the use of the calibrated loop for making a surface count of organisms on agar media (this method had originally been described in $1928^{5}$ as a means of enumerating bacteria in samples of milk). In $1964^{6}$ Leigh and Williams introduced the blotting paper strip method. Finally, in $1965^{7}$ Mackey and Sandys took the business of inoculation outside the laboratory when they published their paper outlining the use of dipspoons.

All of these methods remain in use. Some modifications have been made, most especially in the method of Mackey and Sandys with the introduction of commercial "kits," some bearing two types of indicator medium and others using material other than agar as a support. ${ }^{8}$ We do not wish to discuss

Accepted for publication 14 March 1984 the merits or demerits of the breakpoints commonly used in counting bacteria in urine. Discussions concerning such breakpoints, however, are valid only when they are founded on results which do not vary from operator to operator (and from laboratory to laboratory). In this paper we present a method which we believe approaches this ideal more closely than others currently in use.

\section{Material and methods}

A Hamilton MicroLab $\mathbf{M}$ programmable diluter (VA Howe and Co, London) (Fig. 1) was programmed to perform the sequence of functions shown in the Table. Urine specimens are mixed by inversion. Seventy microlitres is withdrawn and $60 \mu \mathrm{l}$ is dispensed into one well of a microtitre tray for estimation of the number of cells using an inverted microscope. ${ }^{9}$ The remaining $10 \mu$ l of urine is dispensed with $990 \mu \mathrm{l}$ of diluent (sterile peptone) into a $1.5 \mathrm{ml}$ autoanalyser cup (Sarstedt Limited, Leicester); the vortex produced achieves mixing automatically. Then $120 \mu$ l of the diluted sample is taken up and dispensed as six $20 \mu \mathrm{l}$ drops on to a cysteine lactose electrolyte deficient (CLED) agar plate in the pattern shown in Fig. 2. The sixth drop is spread using the tip of the dispenser. All the manipulations above are performed using the automatic diluter.

\section{Program for the Hamilton Microlab M}

Automatically pick up $1000 \mu l$ peptone

Automatically deliver $1000 \mu \mathrm{l}$ peptone

Manually pick up $70 \mu \mathrm{l}$ specimen

4 Manually deliver $60 \mu \mathrm{l}$ specimen to microtitre tray

5 Automatically pick up $990 \mu \mathrm{l}$ peptone

Manually deliver $1000 \mu$ diluted specimen

7 Manually pick up $120 \mu$ l diluted specimen

8/9 Deliver six $20 \mu$ drops separately; five to one side and the last to the opposite side of a CLED plate (spread the latter)

10 Automatically pick up $500 \mu l$ peptone

11 Manually pick up $500 \mu \mathrm{l}$ chloros

12 Manually deliver $1000 \mu$ l of peptone/chloros 


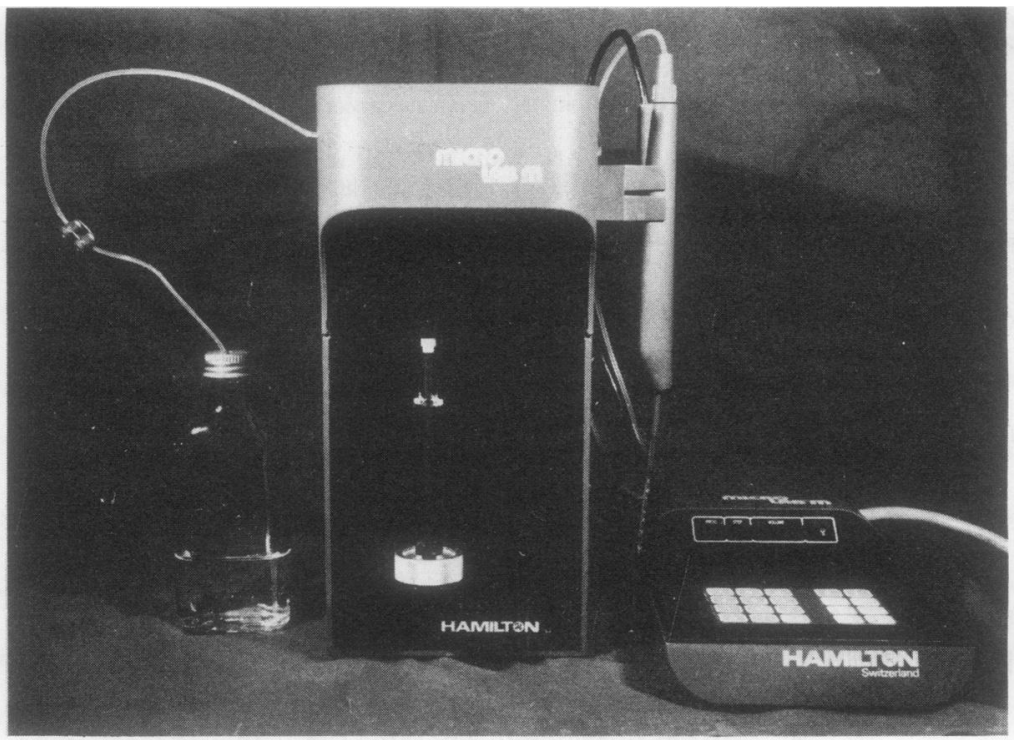

Fig. 1 Hamilton MicroLab M programmable diluter.

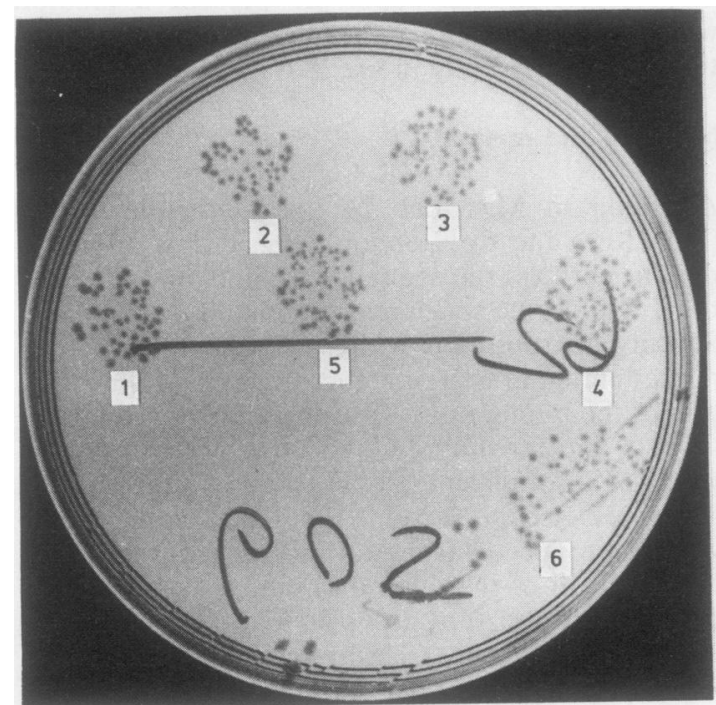

Fig. 2 Pattern of inoculation of CLED plate.

The plates are incubated in an atmosphere containing $10 \% \mathrm{CO}_{2}$ overnight. The next morning the plates are examined. Using the spots numbered 1 to 5 a count is made using an illuminated electric colony counter (Scientifica and Cook Electronics Ltd) (Fig. 3). A total count of colonies in all five spots is made. If the count reaches a value over 100 then it is not taken any further and a value of $>100$ is recorded; otherwise the actual count is recorded.

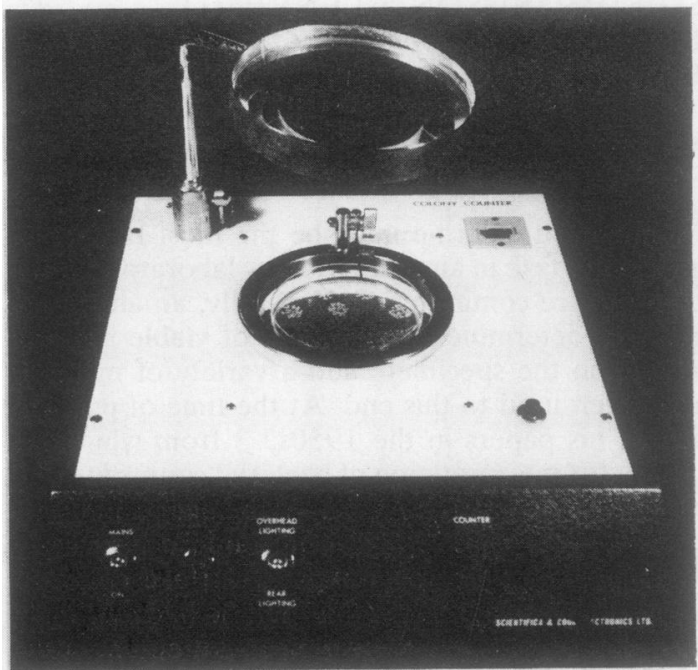

Fig. 3 Scientifica and Cook electronic colony counter.

The total volume of diluted urine sampled in the five spots is $100 \mu \mathrm{l}$. The dilution of the specimen was $1 / 100$ so that the five spots are equivalent to a $1 \mu l$ sample of the original specimen. Thus each colony present is equivalent to $1 \times 10^{6}$ colony forming units per litre (cfu/l)-counts of more than 100 colonies represent "significant growth" $\left(>10^{*} \mathrm{cfu} / \mathrm{l}\right)$ and counts of between 10 and 100 colonies represent "questionable growth" $\left(10^{7}-10^{8} \mathrm{cfu} / \mathrm{l}\right)$. Spot number 
6, which has been spread, allows more certain detection of mixed cultures and allows sampling of single colonies. By examining "dummy" specimens (sterile peptone water) with this method immediately after positive specimens, carry over of bacteria from one sample to the next has not been found to occur.

Where an automatic diluter is not available it is possible to employ an automatic pipette (for example, Eppendorf, Germany) using a separate disposable tip for each specimen. In this case, dilutions are more conveniently made in larger volumes $(60 \mu \mathrm{l}$ in $6 \mathrm{ml}$ ) in plastic or glass containers. The disinfection step using hypochlorite is omitted.

\section{Discussion}

Each method has its own disadvantages and in use there will be a balance between ease of use and accurate enumeration of bacteria. The pour plate method requires considerable skill and colonies may have to be retrieved from the depths of the agar. The loop method of Hoeprich appears to be very simple. Experience shows, however, that to obtain a really even spread requires considerable effort. Much variation may occur between operators, depending on the zeal with which they spread. The blotting paper strip method of Leigh and Williams is quick and is economical of media. Because of the small surface area inoculated, however, examination of specimens containing a mixed population of bacteria may not be easy. Some laboratories have moved towards overcoming some of these difficulties by combining the last two methods: the blotting paper strip method is used as a screen for specimens containing no leucocytes (or only small numbers) and the loop method is reserved for specimens containing leucocytes in numbers exceeding a locally chosen level.

The method that we have outlined for counting bacteria is now in routine use on the urine bench in the microbiology department at Cheltenham. No extra laboratory technician time has been required in order to incorporate this method-the time taken to set up each culture plate is about $30 \mathrm{~s}$. As far as cost is concerned, the major expense is the purchase of the programmable diluter (about $£ 2400$ excluding VAT). In addition, there will be an increase in the amount of agar used (the extent depending on the currently used method).
In principle, this method is the same as that described by Miles and Misra in $1938 .^{10}$ It provides a system for obtaining counts of bacteria in urine which strikes a more satisfactory balance between accuracy and ease of operation. As mentioned above, we have not set out to discuss the validity of the "breakpoints" commonly used in enumeration of bacteria in urine specimens. If, however, there is to be useful discussion on this topic results should be subject to as little variation as possible. A system such as the one presented here should be of value in standardising the results obtained without adding greatly to the time taken to examine each specimen.

We would like to acknowledge the interest and enthusiasm of all the laboratory staff in the department of microbiology at Cheltenham.

\section{References}

' Kass EH. Asymptomatic infections of the urinary tract. Transatlantic Association of American Physicians 1956;69:56-64.

${ }^{2}$ MacDonald RA, Levitin H, Mallory GK, Kass EH. Relations between pyelonephritis and bacterial counts in the urine. $N$ Engl J Medicine 1957;256:915-22.

${ }^{3} \mathrm{Kass}$ EH. Bacteriuria and the diagnosis of infections of the urinary tract. Arch Int Med 1957;100:709-14.

4 Hoeprich PD. Culture of the urine. J Lab Clin Med 1960; 56:899-907.

s World's Dairy Congress. The quantitative smear culture: a simple means for the bacteriological examination of milk. 1928 , 690-7.

- Leigh DA, Williams JD. Method for the detection of significant bacteriuria in large groups of patients. J Clin Pathol $1964 ; 17: 498-503$

${ }^{7}$ Mackey JP, Sandys GH. Laboratory diagnosis of infections of the urinary tract in general practice by means of a dip-inoculum transport medium. Br Med J 1965; ii: 1286-8.

${ }^{8}$ Coltman KMD. Miniaturized culture pads in the detection of bacteriuria. Practice of Medicine 1982;226:751-7.

' Maskell R. Urinary tract infection. London: Edward Arnold, 1982: 24.

${ }^{10}$ Miles AA, Misra SS. The estimation of the bactericidal power of the blood. J Hyg 1938;38:732-49.

Requests for reprints to: Dr SG Edmondson, Department of Microbiology, Cheltenham General Hospital, Cheltenham, England. 